\title{
GLACIATION ON THE ARCTIC SLOPE OF THE BROOKS RANGE, NORTHERN ALASKA*
}

\author{
R. L. Detterman, A. L. Bowsher, and J. Thomas Dutro, Jr. $\dagger$
}

$\mathbf{T}$

HE area discussed in this report is the Arctic Slope of the Brooks Range, northern Alaska. The Brooks Range extends eastward across northern Alaska from Cape Lisburne to the Canadian border (Fig. 1). Its crest lies about 95 miles north of the Arctic Circle and approximately parallel to it. Near the eastern end the peaks rise to 8,000 or 9,000 feet above sealevel. In the central part of the range the higher summits attain about 7,000 feet. The mountains become progressively lower westward toward the headwaters of the Noatak River. At Howard Pass, approximately 2,200 feet above sea-level, the surrounding mountains are about 5,000 feet high. The DeLong and Baird. Mountains, westerly extensions of the Brooks Range on either side of the broad valley of the west-flowing Noatak River, rise to between 4,000 and 5,000 feet above sea-level.

The streams on the north side of the range flow generally northward through deep, U-shaped, glacially sculptured valleys that traverse the Arctic Foothills Province of rolling hills and east-west trending ridges. In the eastern part of the region the streams flow directly into the Arctic Ocean, but in the western part they run first into the Colville River, which flows east and north into the sea. A low ridge that trends east-west lies north of the Colville River. To the north of this ridge extends the Arctic Coastal Plain Province to the shores of the Arctic Ocean.

Most existing glaciers on the northern slope of the Brooks Range originate in the protected parts of the larger, higher, north-facing cirques and do not extend more than 3 or 4 miles from the areas of accumulation. The smaller glaciers seem to be remnants of shrinking valley glaciers. Almost all the smaller cirques at lower levels are ice-free.

Six glaciations of the area have been recognized by an analysis of morphology, composition, and geographic distribution of glacial deposits. Glaciers were of alpine valley type that during the earlier, more extensive advances coalesced to form piedmont lobes. There was no continuous ice-sheet in northern Alaska during any part of the glacial epoch.

The two oldest advances, the Anaktuvuk and Sagavanirktok glaciations, are characterized by deposits that are greatly modified by erosion and mass-wasting. Drift is present as tundra-covered moraines. Most of the former kettle lakes have been filled or drained and drainage patterns are well integrated. These glaciations are considered pre-Wisconsin in age.

The Itkillik and Echooka glaciations, represented by relatively fresh drift, are distinguished by differences of physical characteristics and the distribution of morainal areas. They are thought to be of early Wisconsin age.

* Publication authorized by the Director of the U. S. Geological Survey.

$\dagger$ U. S. Geological Survey. 


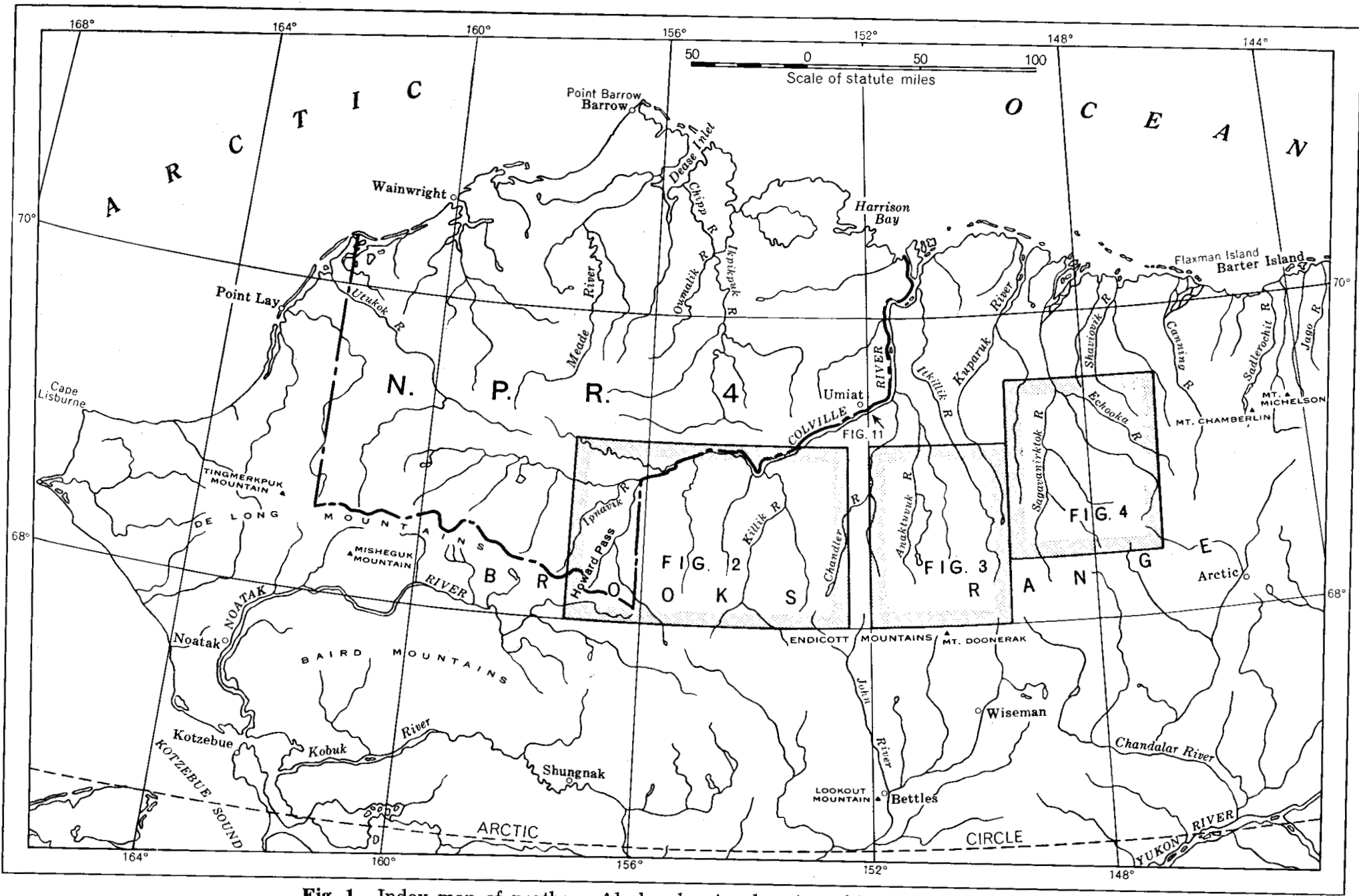

Fig. 1. Index map of northern Alaska showing location of Figs. 2, 3, 4, and 11. 
Deposits of the Alapah Mountain glaciation are little modified by weathering, but are tundra-covered. Morainal areas contain kettle lakes and consequent drainage has undergone little or no modification. This advance is tentatively dated as late Wisconsin.

The Fan Mountain glaciation represents the most recent glacial advance recorded in the region. Moraines are fresh, bare of tundra and generally restricted to the cirque areas. It was obviously a very recent event.

Outwash deposits and loess extend beyond the limits of the northernmost moraines, nearly to the arctic coast. The Gubik formation (Gryc, Patton, and Payne, 1951, p. 167) ${ }^{1}$ of the Coastal Plain area is overlain by a terrace deposit that can be traced to the margin of the Itkillik till sheet. Outwash deposits of the two older glaciations may possibly be included in the Gubik formation as it is now mapped.

\section{Previous work}

F. C. Schrader $(1902,1904)$ was the first geologist to report on glacial phenomena observed in field studies of the Brooks Range. These papers, which contain descriptions of features observed on a reconnaissance up the John River and down the Anaktuvuk River to the Arctic Ocean, present excellent discussions of the glacial deposits that characterize the Brooks Range throughout its length. E. deK. Leffingwell (1919, p. 133) presented detailed discussions of glacial features in the Canning River region in the eastern part of the Brooks Range. P. S. Smith and J. B. Mertie, Jr. (1930, p. 242-247) summarized the knowledge of glaciation in northwestern Alaska and presented data collected during their work on the Arctic Slope and adjoining areas. A few summary remarks about extent and type of glaciation in the Brooks Range are included in papers by S. R. Capps (1931) and P. S. Smith (1939, p. 67-70).

Detterman (1953, p. 11-12) discussed glacial deposits in the Sagavanirktok-Anaktuvuk region, northern Alaska, and proposed the names Anaktuvuk, Sagavanirktok, Itkillik, and Echooka glaciations for the four Quaternary glacial advances recognized in that region.

\section{Present investigations}

This report is intended to provide a more detailed account of the glacial history of northern Alaska than was given by Detterman (Péwé et $a l, 1953$ ) and is based on observations made during investigations of the Naval Petroleum Reserve No. 4 by the U. S. Geological Survey during the period 1944 to 1953 of the nature and extent of glacial deposits. Field parties followed most of the larger rivers on the Arctic Slope, travelled over much

1 The Gubik formation of Pleistocene age ranges in thickness from a few to 150 feet, but is 10 to 30 feet thick in most exposures. It consists predominantly of slightly consolidated, brown or buff gravel, sand, silt and clay. 


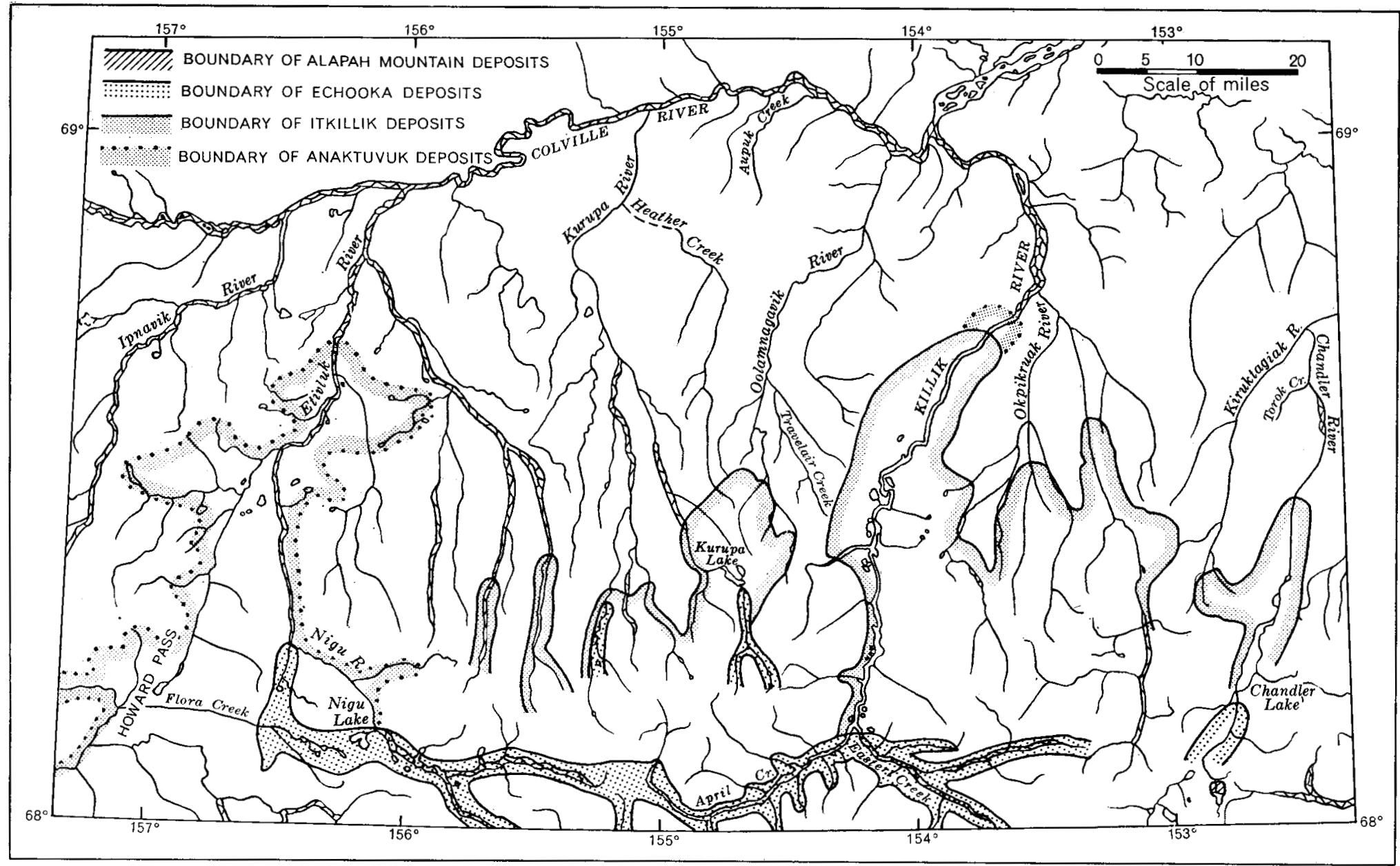

Fig. 2. Distribution of glacial deposits in the Ipnavik-Chandler rivers region. 
of the Foothills Province in tracked vehicles and studied many local areas supported by aircraft equipped with ski or floats. Generally the glacial studies were incidental to work on structure and stratigraphy. Nevertheless, much information on glaciation was obtained for a considerable part of northern Alaska.

This report and the maps showing the distribution of glacial deposits are largely based on work by R. L. Detterman, M. D. Mangus, and R. M. Chapman along the Killik River (Fig. 2), by A. L. Bowsher and J. T. Dutro, Jr., around the Shainin, Nanushuk, and Itkillik lakes (Fig. 3), and by $R$. L. Detterman and A. S. Keller in the eastern part of the Foothills Province (Fig. 4).

In addition, several other geologists of the Geological Survey have contributed remarks and supplementary data on glaciation. Work in the region has been so intimately interwoven that it is not possible to acknowledge every contribution.

This report is concerned with glacial deposits found in the central part of the Brooks Range between Shainin and Itkillik lakes and in the southern part of the Foothills Province from the Shaviovik River in the east to the Etivluk River in the west. Remarks herein concern glaciation only as it affected the north side of the Brooks Range. None should be construed as applying to glaciation on the south side of the mountain chain.

\section{Glacial deposits}

\section{Anaktuvuk glaciation}

The Anaktuvuk glaciation (Detterman, 1953) is named for fragmentary morainal remnants on the Anaktuvuk River, 40 miles north of the mountain front (Fig. 3). The southern edge of the deposit is about 25 miles north of the mountains; it is obscured locally by outwash gravel and till of a younger stage of glaciation.

Deposits of this glaciation have been identified on the Itkillik, Nanushuk, Killik, Nigu, and Etivluk rivers and are probably present on most of the other streams, as this glaciation was apparently more extensive than any of the succeeding advances. Till in the inter-stream areas and erratics on the ridge tops indicate that valley glaciers coalesced to form a piedmont lobe. Conglomeratic quartzite boulders are present on the Nanushuk and Killik rivers 10 to 15 miles north of the morainal belt and may indicate that glaciation was more extensive than mapped on Figs. 2 and 3. On the other hand, these erratics may represent a glaciation that pre-dates the Anaktuvuk advance.

The lower peaks in the Brooks Range, as well as the majority of the ridges in the foothills adjacent to the mountains, were probably covered with ice during the glacial maximum. That the source of some of the ice was south of the mapped area is indicated by granite boulders in the Howard Pass area; the nearest granite is in the mountains along the 


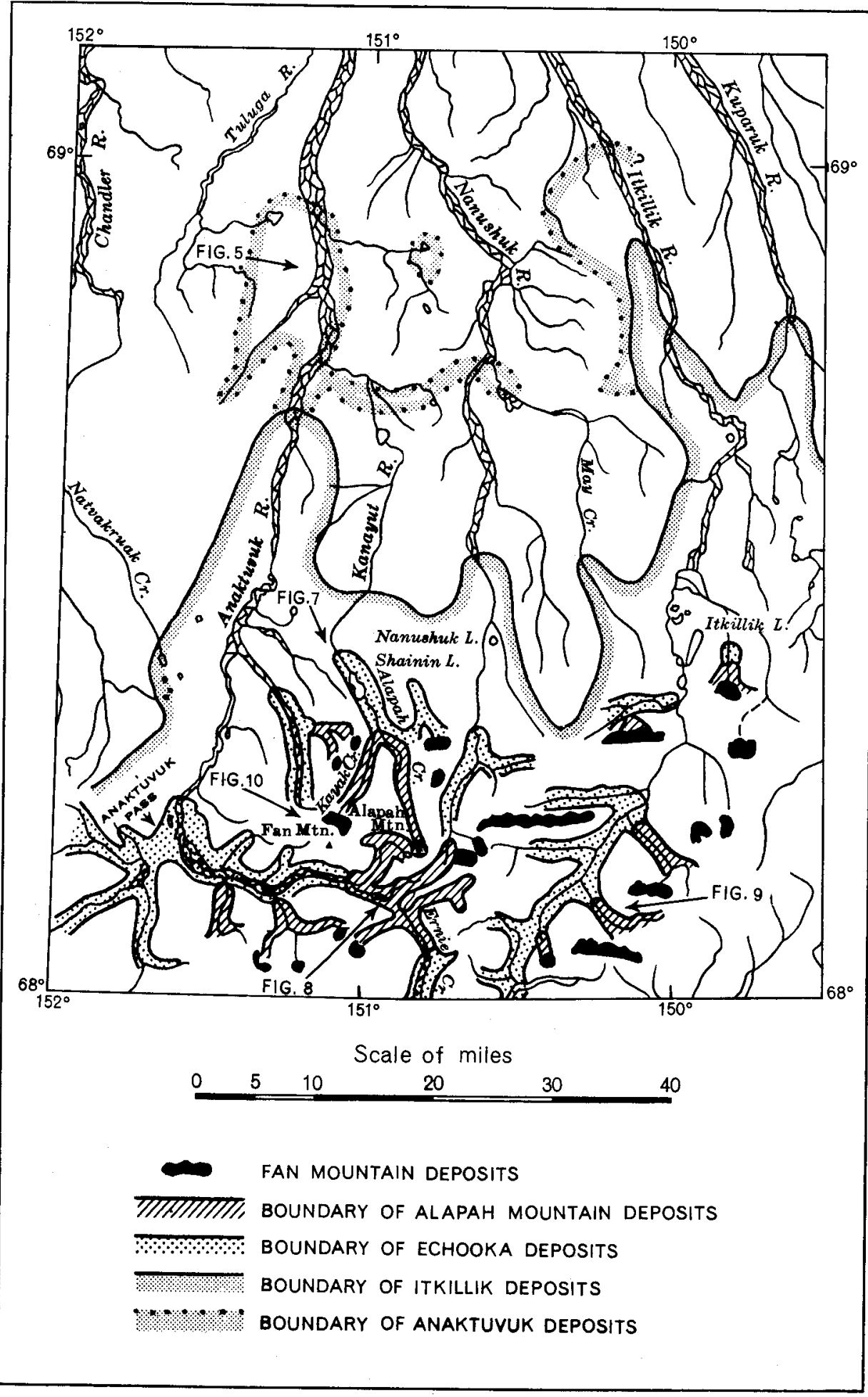

Fig. 3. Distribution of glacial deposits in the Anaktuvuk-Kuparuk rivers region. 


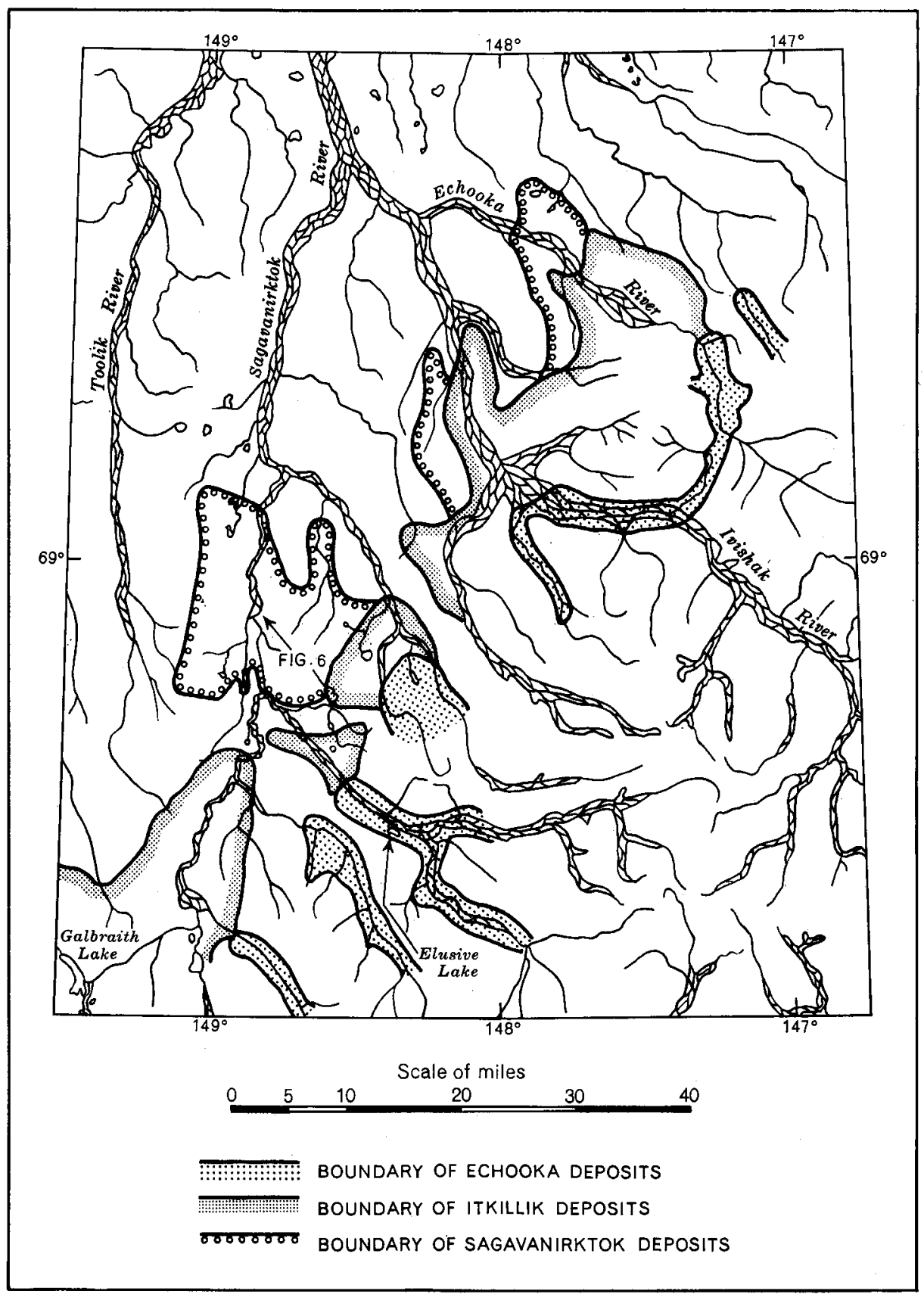

Fig. 4. Distribution of glacial deposits in the Sagavanirktok-Echooka rivers region. 


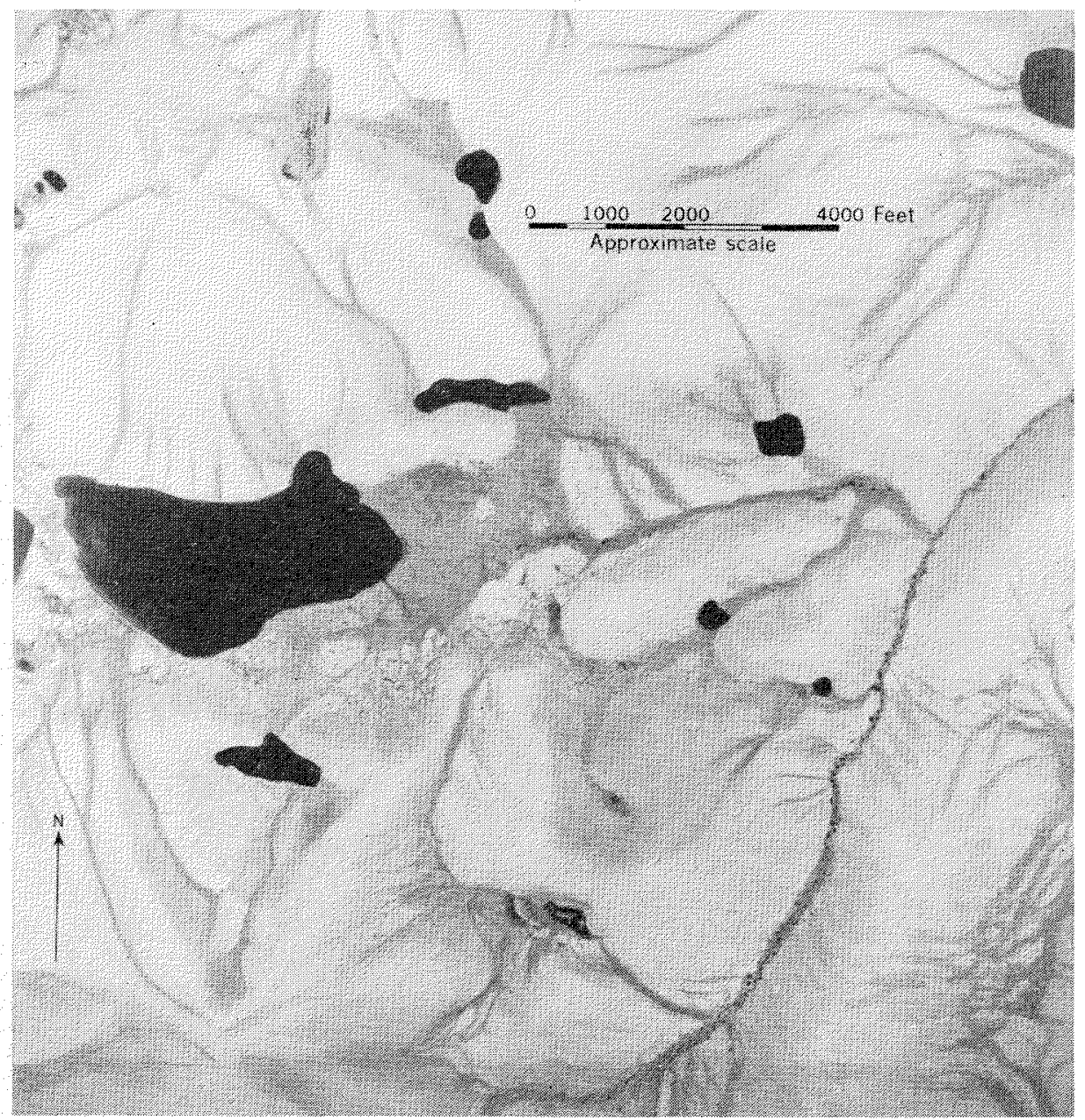

Photo: U. S. Navy

Fig. 5. Drift of the Anaktuvuk glaciation on the west side of the Anaktuvuk River, 30 miles north of the Brooks Range.

Noatak River, 30 miles south of Howard Pass. Glacially sculptured topographic features present in the Brooks Range today may date in part from this advance, but it is believed they were considerably modified by later advances.

Deposits of this glaciation have been considerably modified by erosion and mass-wasting. Lateral and end moraines are no longer identifiable and the drift is preserved as low, rounded, tundra-covered, morainal hills (Fig. 5). Large erratics of quartzite, conglomeratic quartzite, and granite (in Howard Pass) are present on the hilltops, and the morainal deposits consist of smaller fragments of similar composition; any fragments of shale, sandstone, or limestone that may have been present on or near the surface have since disintegrated. Most of the kettle lakes have been filled or drained and the streams are well integrated. 


\section{Sagavanirktok glaciation}

The Sagavanirktok glaciation (Detterman, 1953) is named for morainal remnants along the Sagavanirktok River (Fig. 4), 60 miles east of the Anaktuvuk River. The deposits are separated from younger ones to the south by outwash gravel and their northern limit is about 25 miles north of the Brooks Range.

Deposits of this glaciation have been recognized only in the eastern part of the mapped area, along the Sagavanirktok, Ivishak, and Echooka ${ }^{2}$ rivers; they have not been recognized in areas where deposits of the Anaktuvuk glaciation are present, nor have deposits of the Anaktuvuk glaciation been recognized in areas where the Sagavanirktok glaciation is mapped. The exact relationship between these two advances is not known and it is possible that the Sagavanirktok deposits represent a readvance during the Anaktuvuk glaciation or they may actually be deposits of the Anaktuvuk glaciation. The difference in superficial modification of the deposits, however, is great enough to permit distinguishing them and it seems to indicate a time gap between the two glaciations.

Morainal remnants of the Sagavanirktok glaciation have been considerably modified, but still retain recognizable knob and kettle topography (Fig. 6). Many of the kettle lakes have been filled and streams are well integrated. The lateral and terminal moraines are recognizable in a few places, but for the most part are covered by outwash of more recent advances. Most of the erratics and morainal debris consist of quartzite and conglomeratic quartzite similar to the deposits of the Anaktuvuk glaciation. Limestone fragments are present and may locally constitute as much as 30 per cent of the drift; they are rarely found in the deposits of the Anaktuvuk glaciation.

Deposits along the Sagavanirktok River indicate that the ice coalesced locally to form a piedmont lobe in the foothills area. The depth of ice that filled the mountain valleys is unknown, but quartzite boulders 1,500 feet above the valley floor may date from this glaciation.

\section{Itkillik glaciation}

The Itkillik glaciation (Detterman, 1953) is named for deposits that are well developed along the Itkillik River (Fig. 3), 30 miles east of the Anaktuvuk River.

Deposits of this glaciation are present on all the major streams in the mapped area. The northernmost extent of the advance was about 25 miles from the mountains along the Itkillik River, 10 miles from the mountains in the eastern part of the mapped area, and 30 miles from the mountains along the Killik River.

2 The spelling "Eschooka" instead of "Echooka" in Table 1 of U. S. Geol. Surv. Circ. 289, "Multiple Glaciation in Alaska," is a typographical error. 
This glaciation was the last advance of ice that extended north beyond the mountain front. Piedmont lobes formed in the foothills near the major river valleys; all subsequent advances were restricted to valley glaciers within the mountains. Most of the ice-sculptured topographic features in the mountains probably date from this glaciation. In the Killik River valley the upper limit of ice-action is about 1,800 to 2,000 feet above the valley floor and erratics are found 1,200 feet above the river in the foothills north of the mountains.

Deposits of the Itkillik glaciation are relatively fresh and only slightly modified by erosion. Lateral and terminal moraines are easily recognized, as well as knob and kettle topography of the ground moraine (Fig. 7). Kame terraces and ice-margin stream-channels are present along the valley walls of the larger rivers; numerous kettle lakes, a few tens of feet to half

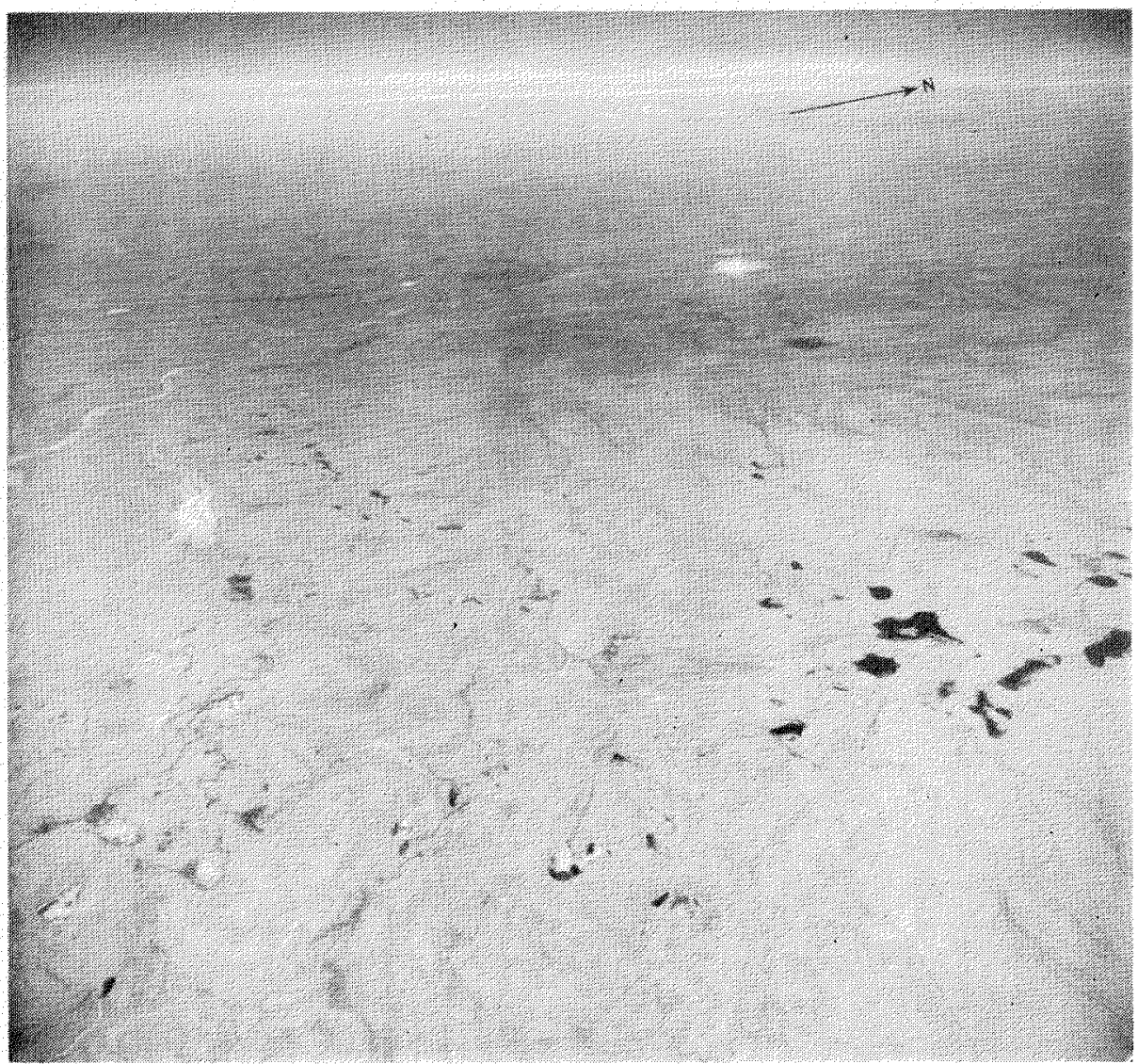

Photo: U.S.A.T

Fig. 6 Deposits of the Sagavanirktok glaciation (background) and Itkillik glaciation (foreground) on the Sagavanirktok River, 12 miles northwest of Elusive Lake. 


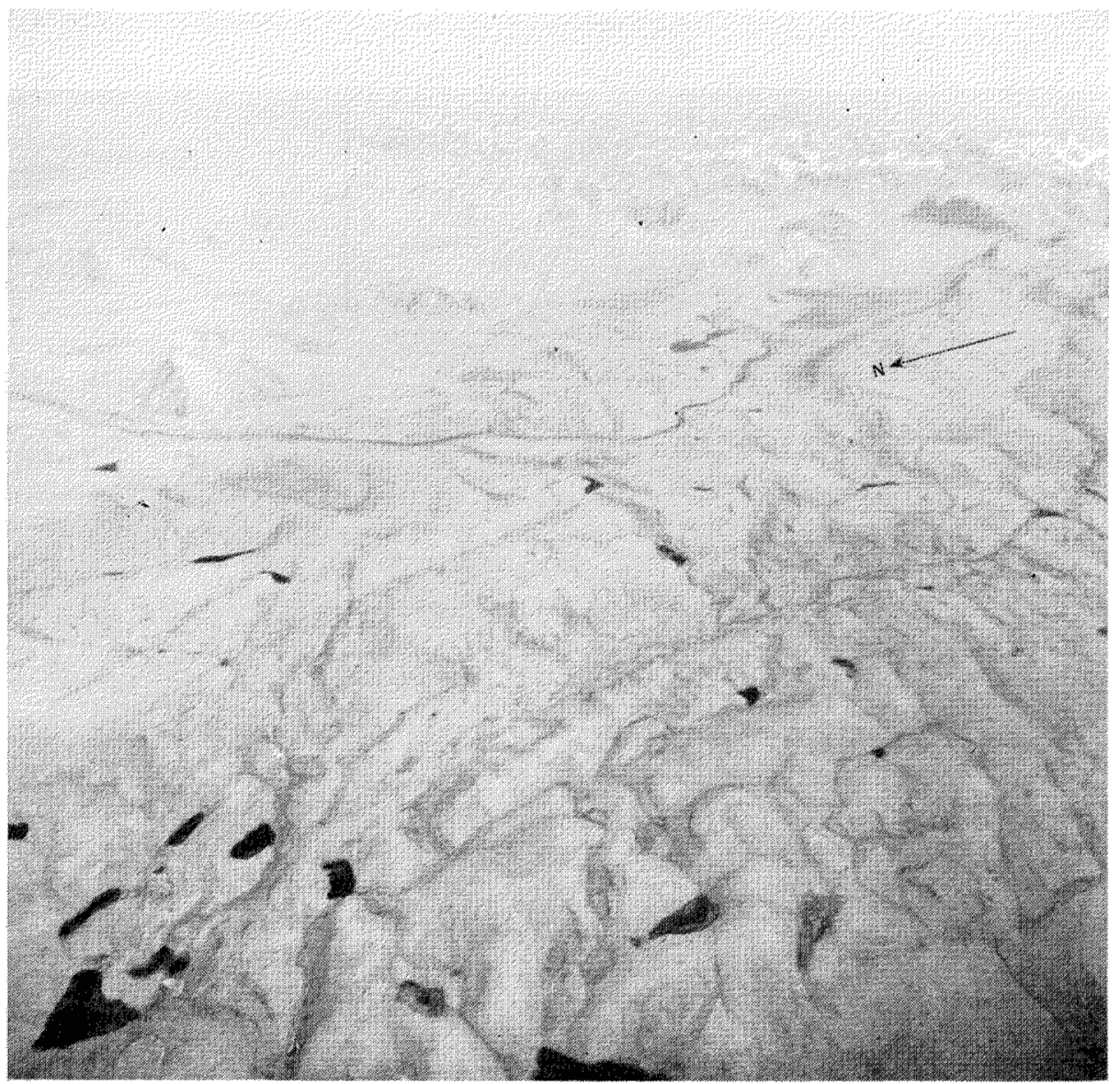

Photo: C.S.A.Y

Fig. 7. Moraines of the Itkillik glaciation (foreground) on the east side of Anaktuvuk River and moraines of the Echooka glaciation at the north end of Shainin Lake (right background). Shainin Lake is dammed by Echooka moraines.

a mile in length, are present on the moraines. The small streams are not well integrated and drainage patterns are arcuate in outline around the perimeter of the moraines. Most of the large lakes in the river valleys at the northern front of the mountains were formed through damming of streams by deposits of this glaciation. Six recessional moraines are present in the Killik Valley, one of which dammed a lake 29 miles long. This lake was partly drained when the river cut through the moraine.

Erratics of the Itkillik glaciation have well developed glacial striations. Locally limestone forms as much as 50 per cent of the erratics and larger rock fragments in the moraines. It appears to be relatively fresh and is only slightly weathered, in contrast to the highly weathered limestone in the older deposits. 


\section{Echooka glaciation}

The Echooka glaciation (Detterman, 1953) is named for the morainal deposits along the Echooka River, a tributary of the Sagavanirktok River in the eastern part of the mapped area (Fig. 4). This relatively minor advance did not reach the mountain front and was confined to the larger river valleys. Small tributary glaciers probably coalesced to form trunk glaciers in the larger valleys, but piedmont lobes were not formed. The more extensive deposits of this glaciation are in the headwaters area of the Killik and Nigu rivers. There are other large areas on the upper parts of the Anaktuvuk, Itkillik, and Kanayut rivers (Fig. 7). Similar, unmapped deposits are probably present in other river valleys.

The Echooka glaciation left well developed, arcuate terminal moraines that cross the river valleys near the mountain front. The kame terraces along the valley walls and the knob and kettle topography of the ground moraines are quite fresh. Kettle lakes are small and have not been filled or drained. Small consequent streams crossing the moraines have not cut deeply into them. The larger rivers, however, have removed a considerable amount of the morainal material from their flood plains.

Drift of this glaciation forms a thin mantle 30 to 50 feet thick, although the lateral and terminal moraines are somewhat thicker. Rock fragments consist of fresh-appearing limestone, sandstone, and quartzite, which are all striated and have fresh, ice-polished surfaces. Small rock fragments are common. The average diameter of erratics is about 18 to 24 inches, whereas most of the drift is composed of gravel and cobbles as much as 6 inches in diameter.

End moraines of the Echooka glaciation are about 20 to 40 miles from the accumulation areas in the cirques. The maximum ice-movement was on the Killik and Nigu rivers, where end moraines are as far as 50 miles from the cirques. Shainin and Elusive lakes were formed behind end moraines of this advance (Fig. 7).

End moraines of the Echooka glaciation are present in nearly all stream valleys in the Brooks Range. The occurrence of end moraines at about the same position in relation to the mountain front is one of the features distinguishing deposits of the Echooka glaciation.

\section{Alapah Mountain glaciation}

The Alapah Mountain glaciation is here deduced from morainal remnants found in the pass between Anaktuvuk River and Ernie Creek (Fig. 8), 16 miles south of Shainin Lake (Fig. 3), these deposits having been formed at the snouts of the glaciers originating on the slopes of Alapah Mountain.

Deposits of this glaciation are not extensive, but small remnants are present throughout the Brooks Range. They have been washed from many of the glacial valleys; where present they lie well back in the range. 


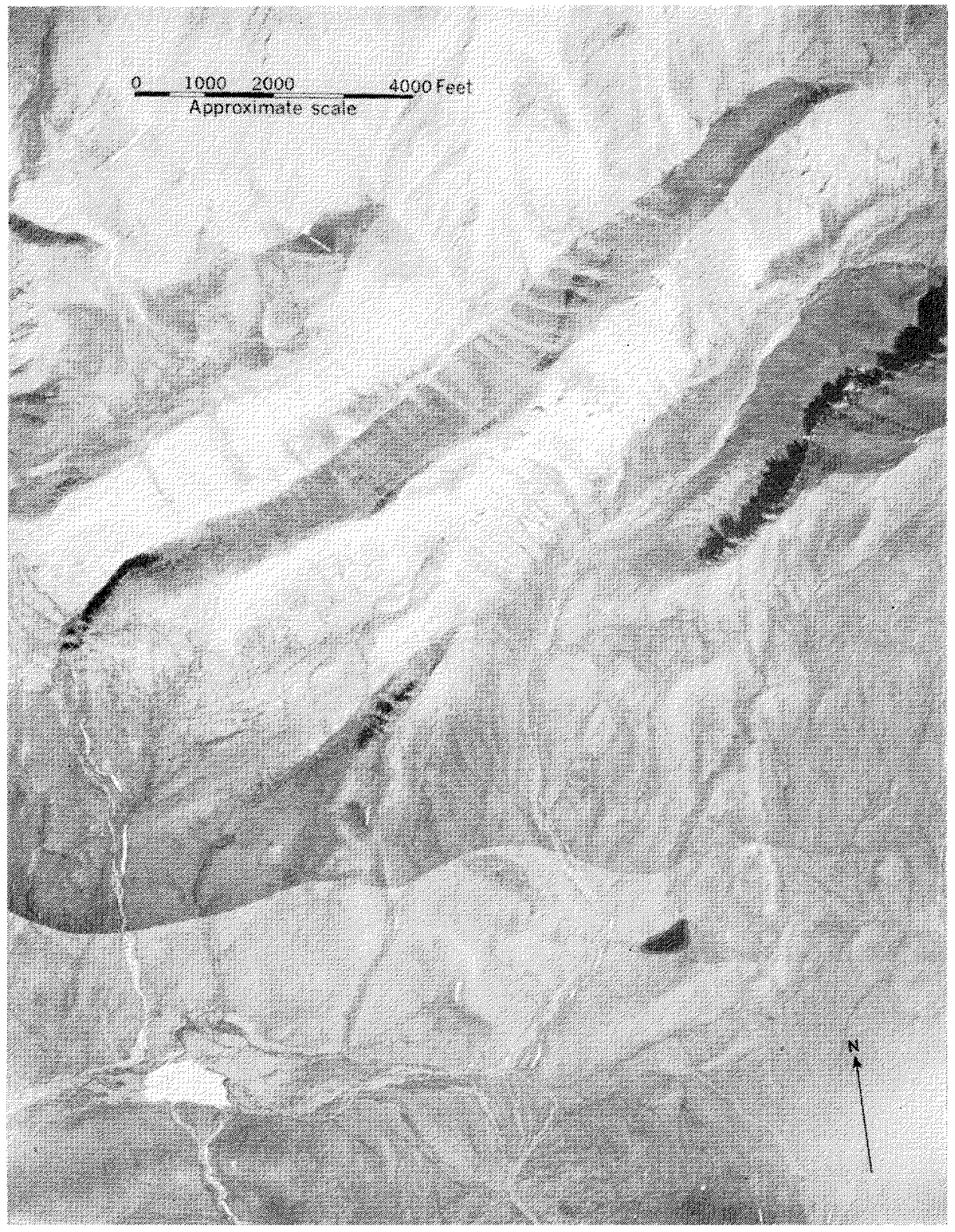

Photo: U.S.A.F.

Fig. 8. Alapah Mountain end moraines in the Anaktuvuk River-Ernie Creek Pass, 4.5 miles southwest of Alapah Mountain.

Poorly developed deposits are recognized 4 miles southeast of Itkillik Lake; reduced remnants of till occur 5 miles southwest of Shainin Lake. Well defined remnants are present at the junction of Alapah and Kayak creeks, 4 miles south of Shainin Lake and there are other deposits in tributary 


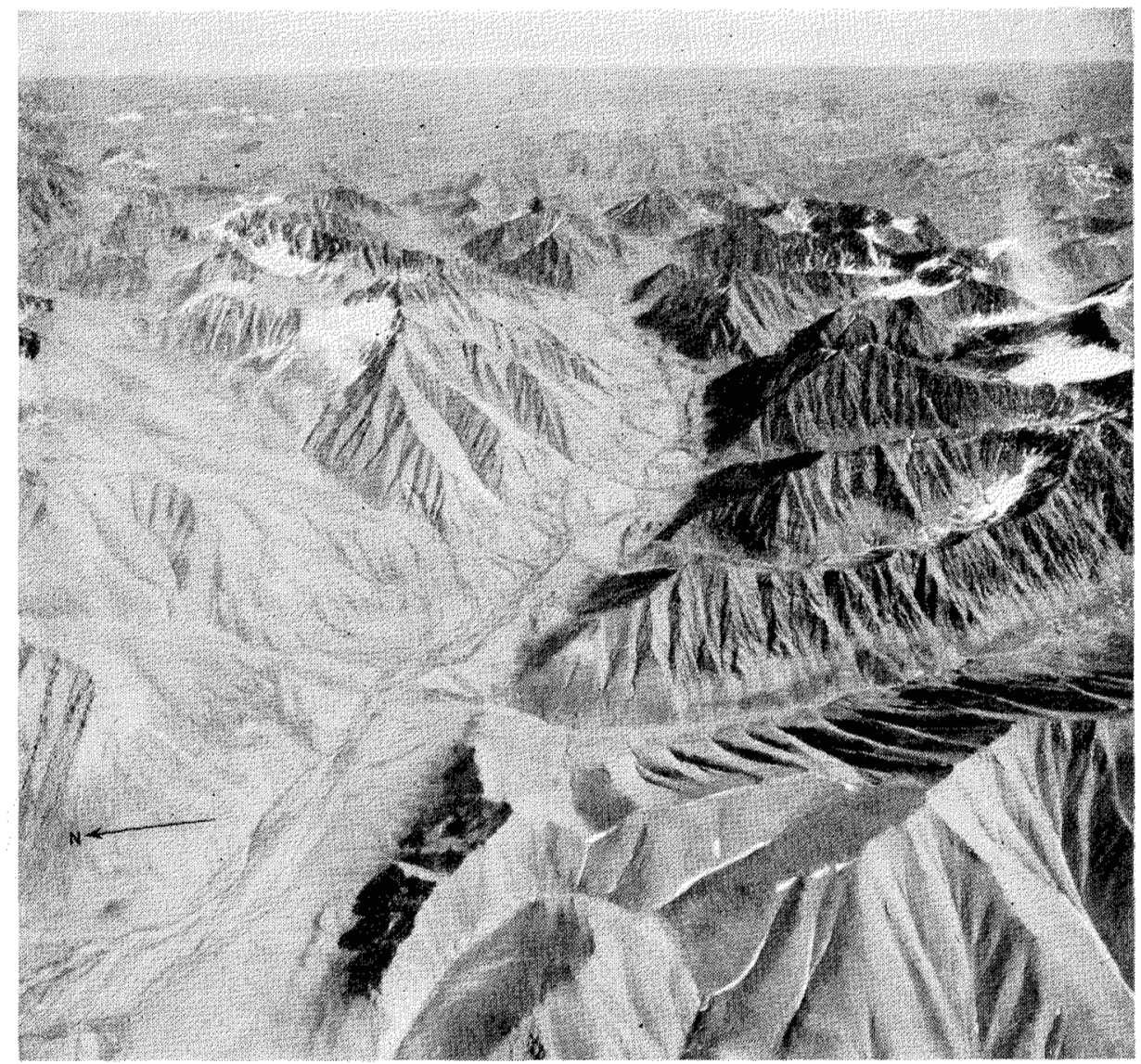

Photo: U.S.A.F.

Fig. 9. U-shaped glacial valleys and glaciers at the head of the Itkillik River, 22 miles south of Itkillik Lake. Fan Mountain deposits are present in some of the cirques. Alapah Mountain deposits are present along walls of the higher valleys and lie along the side of the main valley in the centre of the photograph.

valleys at the head of Anaktuvuk River. Extensive lateral moraines occur in tributaries at the head of the Itkillik River (Fig. 9).

Terminal moraines of the Alapah Mountain glaciation are differentiated from those of the Echooka glaciation partly by their geographical position; they lie 5 miles or more upstream from the Echooka terminal moraines. Moraines of the Echooka glaciation are more extensive, thicker, and slightly more modified by mass-wasting and erosion than those of the Alapah Mountain glaciation. Generally more extensive drift deposits are present between the Echooka and Alapah Mountain terminal moraines than upstream from the last named. The lower walls of the valleys upstream from the Alapah Mountain terminal moraines are characterized by steep slopes with cliffs cut into bedrock. Very little talus has accumulated at the 
base of these slopes and cliffs. Downstream from the Alapah Mountain end moraines talus fans extend well out into the valleys; terraces and irregular patches of drift lie along the base of the valley walls.

Deposits of the Alapah Mountain glaciation, largely covered by tundra, produce conspicuous morainal ridges and patches of till with relatively smooth, rolling surfaces. Some small kettle lakes are present between morainal ridges. Most of these clear-water lakes with gravel-covered bottoms lie in poorly drained areas; very little silt or sand has been transported into them. Drainage is, in general, consequent and controlled by the position of the drift ridges. Drainage channels and the three or four morainal ridges commonly present clearly outline the margin of the ice from which the deposits were derived. The deposits seem to represent a single glacial stagnation. Upstream from the moraines small patches of drift are preserved as terraces or more rarely as lateral moraines along the sides of the valleys. Terminal moraines are found from 3 to $\mathbf{1 0}$ miles downstream from the cirques where the ice accumulated.

The deposits of the Alapah Mountain glaciation consist largely of remnants of unsorted drift, composed of limestone, sandstone, and shale fragments derived from nearby cirques.

Short valley glaciers characterized this glaciation, which represents a late, short-lived advance.

\section{Fan Mountain glaciation}

The Fan Mountain glaciation is here named for glacial deposits found at the thresholds of cirques in the vicinity of Fan Mountain, 13 miles south of Shainin Lake (Fig. 3). Moraines of the Fan Mountain glaciation appear to be present in many cirques in the higher parts of the Brooks Range, generally above an altitude of 4,600 feet in the vicinity of Alapah Mountain (Fig. 10). The distribution of the deposits is shown in Fig. 3.

Most till of this glaciation is fresh and irregular. Tundra vegetation has not yet advanced over these young deposits, which are composed of unsorted, locally derived rock fragments. They do not differ from moraines now forming at the front of existing glaciers. Precise differentiation between till ridges that are being formed at present and Fan Mountain moraines is difficult near the snouts of a few of the larger glaciers where the ice may abut against the Fan Mountain moraines or may actually have overridden them. Kettle lakes are present behind a few of the Fan Mountain moraines. In some ice-free cirques the deposits form an irregular mantle of till; in others they form a single terminal moraine, and in still others as many as six closely spaced morainal ridges. Drainage in these essentially undissected morainal areas is largely by subsurface seepage.

Small glaciers confined to the higher, larger, and mainly north-facing cirques characterized the Fan Mountain glaciation. Numerous ice-free cirques with Fan Mountain moraines indicate the disappearance of many of these glaciers. This glaciation appears to represent an extremely recent and short-lived advance. 


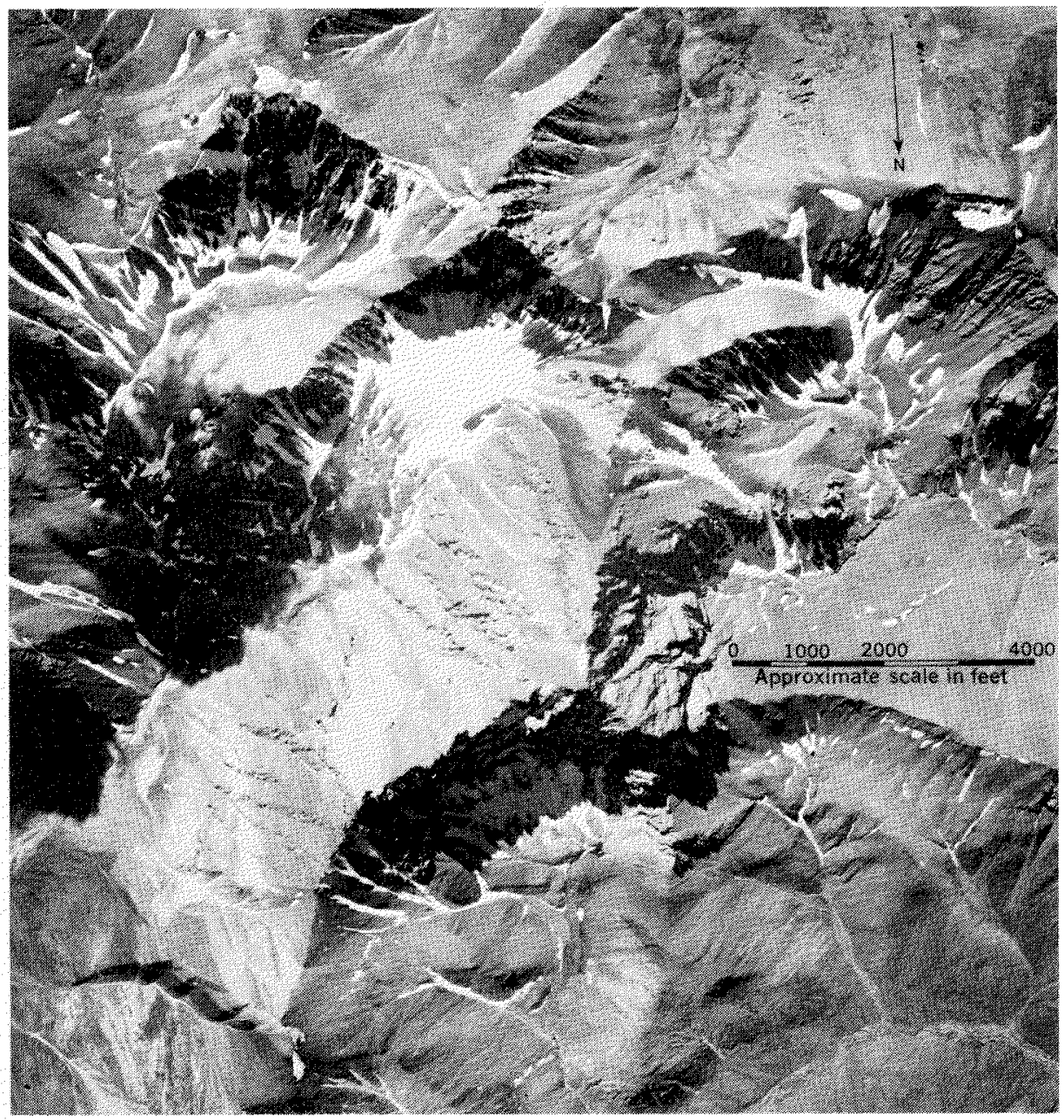

Photo: U. S. Navy

Fig. 10. Deposits of the Fan Mountain glaciation in cirques at the head of Kayak Creek, 3 miles northwest of Fan Mountain. The floors of the cirques are approximately 5,000 feet above sea-level; the peaks rise to nearly 7,000 feet.

\section{Loess deposits}

Deposits formed primarily by wind action, but possibly including some material of fluvial origin, overlie the terrace deposits along the Colville River (Fig. 11) and the lower Chandler, Anaktuvuk, and Nanushuk rivers. Similar deposits are probably present elsewhere, but they have not been recognized. The loess deposits are from 15 to 30 feet thick, buff to brown in colour and are composed of silt particles. The areas covered by loess are of uniformly low relief, have only a few, poorly integrated streams and contain numerous large thermokarst lakes. 


\section{Correlation of the glacial sequence}

The glacial deposits in northern Alaska have not been dated by carbon-14 analyses. Correlation with other glaciations in Alaska and with the standard North American stages is by comparison of physical characters produced by mass-wasting and erosion. The vegetation of the Arctic Slope of the Brooks Range is predominantly tundra, with willow and alder groves along the larger rivers. Surficial modification of glacial deposits by masswasting would therefore be considerably different from that in forested areas.

Each of the six glacial advances recognized in the northern Brooks Range and on the Arctic Slope produced deposits with different characteristics. The differences between some deposits are more pronounced than those between others. They are used together with the patterns of distribution in establishing the sequence shown in Table 1. The most striking

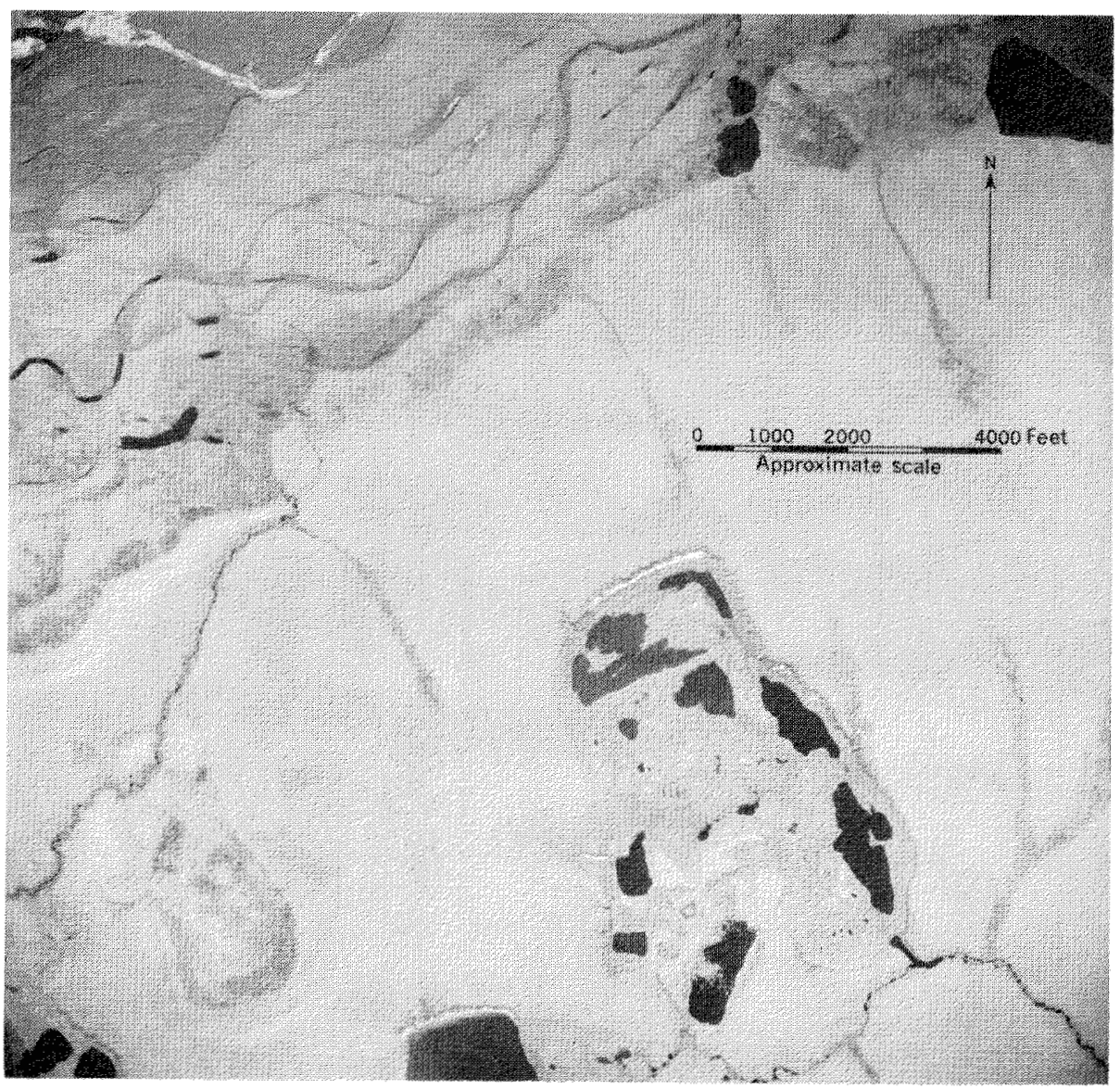

Photo: U.S. Navy

Fig. 11. Thermokarst lakes in loess overlying terrace gravel in the loess belt along the south side of the Colville River near Umiat. 
feature of the Anaktuvuk and Sagavanirktok deposits is their apparently very great age. They are clearly much older than 8,000 years, the age that may be provisionally assigned to the Echooka. In the absence of means of dating other than by physical characteristics, the authors believe that a precise age assignment, other than pre-Wisconsin, would be ill-advised.

Itkillik and Echooka deposits are relatively fresh and somewhat similar in appearance, although minor physical differences and different distributional patterns make a distinction between the two glaciations possible. The possibility that the Echooka represents a major readvance or a period of stand-still within the Itkillik glaciation cannot be ruled out definitely at the present time. The fresh appearance of the drift of these two glaciations would seem to indicate that they are no older than early Wisconsin.

Table 1. Tentative chronology of the glacial sequence in a part of the Arctic Slope of the Brooks Range, Alaska.

Recent
Late Wisconsin
Early Wisconsin
Pre-Wisconsin

Fan Mountain

Alapah Mountain

Echooka

\{tkillik

Sagavanirktok

Anaktuvuk

Three samples of peat obtained by Boston University Physical Research Laboratories from a core in loess near Umiat have been dated by the Lamont Geological Observatory (Broecker, Kulp, and Tucek, 1956). The oldest sample was dated as $8,300 \pm 270$ years before the present. The other two samples have dates of $3,530 \pm 150$ years and $5,890 \pm 170$ years.

The oldest sample, taken from pollen core I of Livingstone (1957, pp. 257-259), was correlated by him with a similar zone at Chandler Lake. Because the precise relationship of glacial deposits to pollen zones in the Chandler Lake region has not been worked out, it seems best to consider this date of slightly more than 8,000 years as representative only of a minimum age for the Echooka glaciation. It may actually be considerably older.

Deposits of the Alapah Mountain glaciation are only slightly modified by weathering. They are, however, covered by tundra, which would indicate that they were not formed within the last one or two centuries. Consequently, the Alapah Mountain advance is tentatively dated as late Wisconsin.

Deposits of the Fan Mountain glaciation, composed of completely bare rock debris are probably of Recent age.

The chronology suggested in Table 1 is somewhat different from that suggested by Péwé et al. (1953, p. 13) or Karlstrom (1957, p. 74). Karlstrom changed the original correlation of Alaskan glacial sequences so that advances older than Naptowne, Brooks Lake, and Farewell were correlated 
with the Illinoian, Kansan, and Nebraskan stages. The greatest change in physical characteristics of the deposits produced by mass-wasting, as described in Péwé et al., appears between Wisconsin and pre-Wisconsin deposits. In the area described in this report it occurs between the deposits of the Sagavanirktok and Itkillik advances; therefore, the Itkillik advance has been dated as early Wisconsin, as originally stated in Péwé et al. (1953).

Quinn (1957, p. 164) has discussed the possible contemporaneity of Texas and Alaska Pleistocene alluviations. Two distinctly different sets of terraces are recognized. Deposits of the older terraces are considered to be pre-Wisconsin and those of the younger terraces are thought to be Wisconsin. Quinn attributes differences in distribution and physical character of these terraces to major climatic changes during the Pleistocene. Differentiation of glacial deposits on the Arctic Slope of the Brooks Range into older (pre-Itkillik) and younger (Itkillik and post-Itkillik) glaciations may be a reflection of similar Pleistocene climatic changes.

\section{References}

Broecker, W. S., J. L. Kulp, and C. S. Tucek. 1956. Lamont natural radiocarbon measurements, III. Science 124:161 (Spec. L-277B, L-277C, and L-277D).

Capps, S. R. 1931. Glaciation in Alaska. U. S. Geol. Surv. Prof. Pap. 170:1-8.

Detterman, R. L. 1953. in Péwé et al. Multiple glaciation in Alaska. U. S. Geol. Surv. Circ. 289:11-12.

Gryc, George, W. W. Patton, Jr., and T. G. Payne. 1951. Present Cretaceous stratigraphic nomenclature of northern Alaska. Wash. Acad. Sci. J. 41:167.

Karistrom, T. N. V. 1957. Tentative correlation of Alaskan glacial sequences, 1956. Science 125:73-74.

Leffingwell, E. deK. 1919. The geology of the Canning River region. U. S. Geol. Surv. Prof. Pap. 109: 130-163.

Livingstone, D. A. 1955. Some pollen profiles from arctic Alaska. Ecology 36:587-600. 255:254-260.

Péwé, T. L. et al. 1953. Multiple glaciation in Alaska. U.S. Geol. Surv. Circ. 289, 13 pp. Quinn, J. H. 1957. Paired river terraces and Pleistocene glaciation. J. Geol. 65: 149-168.

Schrader, F. C. 1902. Geological section of the Rocky Mountains in northern Alaska. Geol. Soc. Am. Bull. 13: 233-252.

Pap. 20:84-91.

Smith, P. S. 1939. Areal geology of Alaska. U. S. Geol. Surv. Prof. Pap. 192:67-70.

Smith, P. S., and J. B. Mertie, Jr. 1930. Geology of northwestern Alaska. U. S. Geol. Surv. Bull. 815:242-247. 